\title{
Bireyve
}

Toplum

\section{Temsili Demokrasinin Krizi ve Bir İleri Demokrasi Talebi Olarak Gezi Parkı Eylemleri}

\author{
Sila SABANCILAR EREN ${ }^{1}$ \\ Yücel ÖZDEN ${ }^{2}$
}

Öz: Bu çalışma Gezi Parkı Eylemleri sürecinde temsili demokrasinin krizlerine yönelik tespitler sunmaktadır. Temsili demokrasi hakkında yapılan tespitler, siyasal iktidarın politikalarına yönelik muhalefet üzerinden şekillenmiştir. Çalışma kapsamında demokrasi krizinin belirdiği alanlar kamusal alanda gerçekleşen tartışmalar nezdinde değerlendirilmiştir. Gezi Parkı Eylemleri Türkiye' de siyasal kutuplaşmanın arttığını gösteren toplumsal bir eylemdir. Siyasal kutuplaşmanın varlığı ise metinde de yer verileceği gibi hem eylemlere katılanların hem de siyasal iktidarın söylemlerinde açığa çıkmaktadır. Çalışma Türk Siyasal Kültürü çerçevesinde Gezi Parkı Eylemleri’ni, kamusal alanda siyasal iletişimin ve diyalogun önemini kanıtlayan ve demokrasi krizinin bu yöntemle çözülebileceğini gösteren toplumsal bir hareket olarak ele alınmaktadır. Bu eylemlerin ortaya çıkma nedeni, karar alma sürecinde siyasal iletişimin yeterli düzeyde gerçekleştirilememesine ve toplumsal muhalefetin taleplerinin dikkate alınmamasına bağlamaktadır. Gezi Parkı Eylemleri, siyasal iktidara yönelik muhalefetin yansıması olarak ele alındığında iktidar ve muhalefetin tutumları farklılık göstermektedir. Çalışma farklı bakış açılarının demokrasinin bir boyutu olduğundan hareketle

1 Bitlis Eren Üniversitesi Sosyal Bilimler MYO Öğretim Görevlisi, ssabancilar@beu. edu.tr.

2 Bitlis Eren Üniversitesi Sosyal Bilimler MYO Öğretim Görevlisi, yozden@beu.edu.tr. 
toplumsal uzlaşmanın müzakereci demokrasi aracilığıyla sağlanabileceği iddiasını taşımaktadır. Çünkü demokrasi kavramsal olarak heterojenliği bünyesinde barındırmaktadır. Ancak heterojenlik birbirinden farklı düşüncelerin bir arada bulunmasını engellememekte aksine demokrasi için zenginlik olarak değerlendirilmektedir. Bu çalışmayla demokrasiye yeni bir paradigma kazandırmak amaçlanmaktadır. Demokrasinin oy oranlarından daha fazlasını ifade ettiğini esas alarak, kamusal kararların müzakere yoluyla meşruiyetini sağlayabileceğini savunmaktadır.

Anahtar kelimeler: Gezi parkı eylemleri, Demokrasi, Temsili demokrasi, Müzakereci demokrasi.

\section{Giriş}

Gezi Parkı Eylemleri “Taksim Yayalaştırma Projesi”ne karşı çevreci bir hareket olarak doğmuş sonrasında hükümet karşıtı protestolara dönüşmüștür. 27 Mayıs-25 Haziran 2013 tarihlerinde Türkiye’nin 79 ilinde hükümet karşıtı, eş zamanlı toplumsal muhalefet eylemleri yaşanmıştır. Gezi Parkı Eylemleri’ni doğuran temel neden siyasi iktidarın uygulamalarından memnun olmayan yurttaşların demokratik talepleridir. Bu durum temsili demokrasi krizi olarak yorumlanabilir. Zira Gezi Parkı Eylemleri'nin nedenleri incelendiğinde kamusal yararın toplumsallaşt1rılamadığ gözlemlenmektedir. Bir toplumsal hareket olarak değerlendirebileceğimiz Gezi Parkı Eylemleri kamusal alanda yer alamayan tüm toplumsal taleplerin dişavurumudur. Siyasal iktidarın konsensüse dayanmayan kararlarına karşı bir tepkidir.

Kendiliğindenci, sosyal medya üzerinden örgütlenen, farklı değerlerin dayanışmasını yansıtan bu toplumsal hareket eylem dili ile demokrasiye yeni bir paradigma kazandırmıştır. Bu paradigma temsili demokrasinin tıkanıklıklarını ortaya çıkarmış, ve buna karşın çözüm aracı olarak da toplumsal diyalogun gerçekleştirilebileceğini göstermiştir.

Gezi Parkı Eylemleri temsili demokrasinin yaşadığı krizin dışavurumudur. Temsili demokrasi, demokrasinin uygulanabilirliğini göstermektedir. 
Temsili demokrasi egemenliğin halkın seçtiği yöneticiler aracılığıyla kullanılmasıdır. Siyasal kararları belirleyenleri ve toplumu yönetenleri seçebilme anlamında bu demokrasi modeli meşrudur. Çünkü siyasal iktidar toplumun tercihleri doğrultusunda belirlenmektedir.

Seçimle iş başına gelen iktidarın meşru olmadığı düşüncesi gerçekçi bir bakış açısını yansıtmaz. Ancak siyasal iktidarın aldığı kararların meşruluğu her zaman tartışılabilir. Zira alınan kararların meşruluğunu belirleyen, kararlardan etkilenecek olanların karar alma sürecine özgürce katılabilmesidir (Köker, 1996: 110). Halkın, siyasal kararlara katılma sürecine dahil edilmemesi/olamaması bu kararlara karşı toplumsal muhalefet yaratabilir. Gezi Parkı Eylemleri de bu sebeple oluşan toplumsal muhalefetin yansımasıdır. Kamuoyu görüşüne başvurmama ya da oluşan muhalefeti göz ardı etme siyasal iktidarın meşruiyetinin sorgulanmasina neden olmuştur.

Liberal demokrasilerin yaşadığı bu temsiliyet krizine alternatif oluşturacak demokrasi modeli, müzakereci demokrasidir. Müzakereci demokrasi, siyasal kararların alınmasında müzakere ve diyalog sürecine atıf yapmaktadır. Ayrıca müzakere sürecinin dış baskı olmaksızın, eşit, açık, kapsamlı ve önyargılardan arınmış olması da bu modelin tamamlayıcısıdır (Tunç, 2008: 1129).

Gezi Parkı Eylemleri Türkiye'de demokrasi algısını değiştirmiştir. Yurttaşlar sadece seçim zamanlarında yönetime katılmayı değil daha ileri boyutta kamusal kararlara katılım isteklerini ifade etmişlerdir. $\mathrm{Bu}$ çalışmada demokrasi kavramının niteliği üzerinde durularak Gezi Parkı Eylemleri'nde temsili demokrasi krizinin boyutları ve bu krizin nasıl aşılabileceği tartışılacaktır. Çünkü Gezi Parkı Eylemleri toplumun kutuplaşmasının sonucu olarak da değerlendirilebilir. Bu sorunun aşılması Türkiye'de demokrasinin derinleşmesine katkı sağlayacaktır.

\section{Demokrasi ve Temsili Demokrasi Kavramı}

Çok yönlü ve kapsamlı bir kavram olan demokrasi pek çok düşünür tarafından çeşitli şekillerde ifade edilmiştir. Kavramsal olarak 
"halk iktidarı, iktidarın halka ait olması" şeklinde tanımlanan demokrasi, Yunanca "demos" (halk) ve "kratos" (iktidar) sözcüklerinden türeyerek, İ.Ö. 5 yüzyılda ortaya çıkmış ve o tarihten itibaren siyasal bir kavram olarak kullanılmıştır (Sartori,1996: 9).

Lipset demokrasiyi, yönetimin görevlilerini değiştirmek için anayasaya uygun düzenli imkanlar sağlayan bir siyaset sistemi ve nüfusun mümkün olan en geniş kısmının, siyasal iktidar için yarışanlar arasında bir seçme yaparak önemli kararları etkilemesine izin veren bir sosyal araç olarak tanımlamaktadır (Lipset,1964: 25). Benhabib'e göre demokrasi, ahlaki ve siyasal eşit olarak kabul edilen bireysel ve kolektif kimliklerin kendi yaşam tarzlarını etkileyen kararlar üzerinde özgür ve makul sorgulama, tartışma olanağı buldukları ve bu anlamda karar alma süreçlerine katıldıkları bir kamusal iktidar pratiğidir (Keyman, 2000: 134).

Dahl (2010: 48-56) demokrasinin sonuçlarını; zorbalığı önlemek, temel haklar, genel özgürlük, kendi kaderini tayin etme, ahlaki özgürlük, insani gelişme, temel kişisel çıkarların korunması, siyasal eşitlik, barış ve refah şeklinde sınıflandırmıştır. Bu yönleriyle demokrasi yurttaşların siyasal ve sosyal yeteneklerini geliştirmeye imkân tanıyan bir yönetim biçimidir. Tosun (2001: 99), demokrasi kavramının üç farklı içeriksel tanımlaması olduğuna dikkat çekmektedir. Bu bağlamda muhalif içerikte kullanıldığında, demokrasinin ne olmaması gerektiğini; gerçekçi yaklaşımda ne olduğunu ve ütopik yaklaşımda, mükemmel toplumun nasıl olması gerektiğini anlatır. Demokrasi ile toplumun tamamını memnun edecek kararların alınabilmesi ütopik gibi görünse de toplumsal uzlaşıya ulaşmak mümkün olabilir. Ancak toplumsal uzlaşının nasıl sağlanacağı hangi demokratik paradigmanın esas alınacağı ile ilgilidir.

Demokratik süreç, bireysel özgürlüklerin ve hakların hukukun güvenliği altına alındığı bir süreçtir. $\mathrm{Bu}$ süreç kişinin gelişimini sağlarken, aynı zamanda kişinin iradesini siyasal alana yansıtmasını da sağlamaktadır. Demokrasi özellikle, kişinin siyasal sürece katılmasını ve taleplerini ifade etmesini sağladığ 1 için önemlidir. Bu durum toplumsal bütünleşme ve iktidarın meşruiyetini de sağlamaktadır.

Demokrasi azınlıklara ve özgürlüklere saygı göstermesinin yanı sıra muhalefetin varlığını da tanıyan bir sistem olarak tanınmaktadır (Işık, 
2005: 114). Ayrıca, demokrasi istenmeyen yönetici ve yönetim şekillerini değiştirmenin bir yolu olarak tanımlanmaktadır. Kimin yöneteceği sorusu ise, iktidardaki istenmeyen yöneticilerin şiddet kullanılmaksızın, nasıl olaysız bir şekilde uzaklaştırılacağı ile ilgilidir (Erdoğan, 2003: 232). Demokrasi her ne kadar tüm toplumu memnun eden kararlar veremese de en anlamlı özelliği memnun olunmayan iktidarın değiştirilmesine yönelik kamusal bir karardır.

Paul Hirst, demokrasinin halkın kamusal eylemlerin tercih edilmesinde siyasal bir mekanizma olarak kabul edilmesinde farklı karar alma süreçlerini ortaya çıkardığını söylemektedir. Bu da bu siyasal mekanizma ve karar alma süreçlerinde çeşitli görüşlerin ortaya çıkmasına neden olmaktadır. Bu tanımda demokrasi, temsili ve sorumlu yönetim kurumlarını, bunların belli aralıklarla yasalar çerçevesinde kontrol edilmesini ve sorumluluklarının hukuk çerçevesinde düzenlenmesini, karşıt görüşlerin varlığını sürdürülebilmesini, karar alma sürecine katılımın genel ve geniş çapta olmasını, bireysel hak ve özgürlüklerini mevcudiyetini, çoğunluğun karar alma mekanizmasında etkin olmasinın yanında azınlık haklarına saygıyı çağrıştırmaktadır (Tosun, 2001: 99). Kuşkusuz anayasal yönetimler demokrasinin vazgeçilmez unsurudur. İktidarın anayasaya bağlı olması toplumsal güven açısından önem taşımaktadır. Siyasal katılım ve muhalefet ise demokrasinin derinleşmesinin önemli bir boyutudur.

Demokrasinin bu nitelikleri kuşkusuz onu önemli bir yönetim biçimi haline dönüştürmektedir. Ancak demokrasinin bu niteliği temsiliyet ve meşruiyet krizleri yaşamasına engel olamamaktadır. Temsili demokrasinin meşruiyet krizlerini Kapani (2010: 90) iki nedenle açıklamaktadır: ilk olarak iktidarın kendi hukuki dayanağını oluşturan kurallarına uymamak, onları kasıtlı ve sistemli olarak çiğnemek ve ikinci olarak da iktidarın yürürlükteki hukuk kurallarına uymasıyla birlikte zamanla toplumda hakim olan meşruluk anlayışının ve inancının değişmesidir.

Toplumsal ilke ve değerlere yabancılaşma olarak tanımlayabileceğimiz meşruiyet krizi, siyasal sorunlar karşısında bireylerin ilgisiz kalmasına veya siyasal sisteme karşı güvensizlik duyarak itiraz etmelerine 
neden olacaktır (Arı, 2004: 27). Bu bağlamda Gezi Parkı Eylemleri’ni siyasal iktidarın meşruiyet krizi olarak yorumlayabiliriz. Çünkü çevre hakkı başta olmak üzere özel hayata müdahale noktasında siyasal iktidar ciddi biçimde eleştirilmiştir.

Gezi Parkı Eylemleri’nde dile getirilen eleştirilere karşı siyasal iktidarın oy oranları katılımcılara sürekli hatırlatılmıştır. Oy oranlarının meşruiyetin tek nüvesi olmadığı gerçeğinden hareketle yaşanan kriz "halkın iradesinin seçili temsilcilerin iradesiyle kısıtlanması" (Şimşir (Ed. Bican), 2008: 112) bağlamında somutlaşır.

Temsili demokrasinin yaşadığı meşruiyet krizi Köker (1996: 110) tarafından şu şekilde özetlenmektedir:

1. Devlet karşısında bireyi koruyan bireysel hak ve özgürlüklerin siyasal kararlara katılımdan ziyade bireyin güvenliğiyle işlevlendirilmesi,

2. Devletin kurumsal yapısındaki hiyerarşik ve oligarşik yapılar,

3. Yeni oluşumların kolektif kimliklerde tanınma talebini derinleştirmesi,

4. Yaşam tercihlerinin bireysel alana ilişkin olması sebebiyle devletin tarafsız kalması gerektiğini kabul eden anlayışı,

5. Modern ve anayasal devletin varlığı ve bekasıyla ilgili kaygıların siyaset olarak algılanması.

Köker'in açıklamaları 1şı̆̆ında Gezi Parkı Eylemleri değerlendirildiğinde bireysel hakların siyasal kararlara katılma noktasında potansiyelin açığa çıkarılmasında engellerle karşılaştığı gerçeklik taşımaktadır. Zira Toplantı ve Gösteri Yürüyüşü hakkı kapsamında devlet gücünün orantısız bir biçimde kullanılması ölüm ve yaralanmalara yol açmıştır. Eyleme destek verenlerin "darbecilikle" suçlanması da devletin devamlılığ 1 noktasında ele alınmıştır.

Demokrasinin özü olan anayasal demokrasi ve bireysel hak ve özgürlüklerin hukuk çerçevesinde korunması gereken önemli değerlerdir. Hukuk devleti, yöneten kesimin otoritesi ile yönetilenlerin hak ve özgürlükleri arasında bir denge gözetmeye çalışır. Tüm bu dile getirilen 
ilke ve mekanizmalar demokrasinin standartları olarak kabul edilir. Yalnız şunu da unutmamak gerekir ki demokrasi olanla olması gereken arasında gidip gelmektedir. Uygulamada demokrasi çoğu zaman olması gerekeni veya idealize edileni yansitmamaktadır. Sartori "gerçek demokrasi ile ideal demokrasiyi aynı şey olarak algılamamak" (Işık, 2005: 115) gerektiğini belirtmiştir. Demokrasi standartlarının düşük olduğu ülkelerde, sadece bir yönetim biçimi (hükümet şekli) olarak alg1lanırken, standartların yüksek olduğu yerlerde ise bir siyasal mekanizmadan çok idealler ve değerler bütünü olarak algılanmış ve toplumsal bir yaşam tarzına dönüşmüştür (Tosun, 2001: 100).

Açıklamalardan da anlaşılacağı üzere demokrasi ve demokratik uygulamalar ülkeden ülkeye farklılıklar göstermektedir. Türkiye açısından bu değerlendirme yapıldığında Gezi Parkı Eylemleri'nin demokratikleşmeyi sadece hükümet sistemi olarak algılamadığı açıktır. Gezi Parkı Eylemleri’nde, siyasal iktidarın uygulamalarına karşı demokrasi algısını etkileyen toplumsal talepler yükselmiş ve bu eylemler demokrasinin sadece oy oranları ile açıklanamayacağını göstermiştir.

Bu anlamda, 2011 Genel Seçim Sonuçlarına göre Ak Parti \% 49.9 oy oranıyla iktidar partisi olmuş ve hükümeti kurmuştur. Ancak bu noktada sorgulanması gereken, oy oranları her zaman gücü ve meşruiyeti içerir mi? Bu sorulara cevap arayan Walzer ve Habermas'in görüşlerine yer vermek açılayıcı olacaktır.

Walzer, oy belki bir çeşit güçtür; ama tercihler, etkileme, ikna, baskı, pazarlık, örgütlenme gibi unsurlara dayanır ve ikna gücünün tükendiği noktada tek başına oy zorlayıcı güç olarak meşru değildir, görüşünü savunmaktadır (Mansbridge, 1999: 79). Bu bağlamda liberal temsili krizin yaşadığı meşruiyet krizini aşmanın yolu, müzakereci demokrasi anlay1şının benimsenmesi olacaktır. Zira Müzakereci Demokrasi, temsil esası yerine vatandaşların karar alma sürecine katılımına yani kararların müzakere ile oluşmasına vurgu yapmaktadır. (Tunç, 2008: 1124). Temsili demokrasinin toplumsal taleplere cevap verememesi farklı kimliklerin nasıl birlikte yaşayabileceği sorusunu gündeme getirmiştir. Farklılıkların 
zenginlik olarak yorumlanması ve ötekileştirmemek olgusunu bu noktada temel almak yanlış olmayacaktır.

Gezi Parkı Eylemleri bu bakış açısıyla değerlendirildiğinde, Taksim Yayalaştırma Projesi'ne olan itirazların ve yargı kararlarının dikkate alınmaması siyasal iktidara güvensizliği doğurmuştur. Benzer biçimde alt başlıklarda daha detaylı tartışılacak olan kültürel mirasların Kentsel Dönüşüm kapsamında gözden çıkarılması başka bir toplumsal eleştiriye neden olmuştur. Dolayısıyla kamuoyu desteğinden yoksun olan siyasi kararların farklı toplumsal kesimleri rahatsız etmesi ve örgütlenmesi temsili demokrasinin ihtiyaçları karşılamakta zorluk çektiğini göstermektedir. Bu nedenle de demokrasiye daha farklı nitelikler kazandırmak gereklidir. Meşruiyet ancak toplumsal rıza ile sağlanabilir.

Habermas'a göre de tek meşru güç zorlamadan uzak iletişim içinde ortak kanaatler oluşturanlar arasında ortaya çıkmaktadır (Aktaran Mansbridge, 1999: 79). Demokrasinin gerek duyduğu zorlamanın meşruiyetinin ise; dolaylı/dolaysız rıza, temel adalet ilkelerini benimseme, muhalif grupların eşit güce sahip olmasıyla sağlanabileceğini ifade eden Mansbridge pek çok demokrasinin kapitalist niteliği sebebiyle eşitsizliklere kaynaklık ettiğinin de altını çizmektedir (Mansbridge, 1999: 80-88). Demokrasi, bütün yurttaşların toplumsal konuma ve güce bakılmaksızın taleplerini ortaya koymak için eşit söz hakkını gerektirmektedir (Young, 1999: 177).

Özetle halkın yönetimi olarak adlandırılan demokrasi yöneten-yönetilen ikilemini dengeli bir biçimde çözüme bağlamalıdır. Bu anlamda, zaman içerisinde geliştirilen birçok teori günümüzde devletlerin temsil anlayışında etkisini göstermektedir. Diğer taraftan, demokrasinin, ideali arayan bir yönetim modeli olduğu göz önüne alındığında temsil anlayışında sürekli yenilenmeler olması doğaldır.

Karpat, Türkiye’nin tarihini demokratikleşme girişimlerinin tarihi olarak tanımlamakta ve tam bir demokratikleşmenin sağlanamadığını vurgulamaktadır (Karpat, 1996: 23). Bu durumun, bireyleri devlete hizmet ettiği ölçüde önemseyen devlet algısı, hakim paradigma ve demokrasiyi içselleştirememiş toplumdan kaynaklandığını söyleyebiliriz. 


\section{Gezi Parkı Eylemlerinin Gelişim Seyri ve İleri Demokrasi Talebi Olarak Gezi Parkı Eylemleri}

Gezi Parkı Eylemleri 2013'ün Haziran ayında Taksim Meydanı Yayalaştırma Projesine tepki olarak doğmuş ve hükümet karşıtı gösteriler şeklinde toplumsallaşmıştır. Gezi Parkı Eylemleri'nin çıkış noktası bu proje olarak ele alındığında Gezi Parkı̀nın idari ve siyasal olarak nasıl eyleme dönüştügünün açılanması faydalı olacaktır. Bu nedenle önce idari süreç sonrasında siyasal süreç değerlendirilecektir.

Gezi Parkı 1993 yılında Kentsel Sit Alanı kapsamına, 1999 yılında Korunması Gereken Kültür Varlığı, 2001 yılında Korunması Gereken Önemli Alan olarak değerlendirilmiştir. 2009 yılında Beyoğlu Kentsel Sit Alanı Koruma Amaçlı Nazım İmar Planı Büyükşehir Belediye Meclisince kabul edilip 2010 yılında Belediye Başkanınca onaylanmıştır. 2011 yılında kalıntısı bulunmayan Taksim Kışlası Korunması Gereken Kültür Varlığı olarak tescil edilmiş, 2012 yılında Tabiat Varlıklarını Koruma Bölge Kurulu Gezi Parkinın da dahil olduğu Taksim Yayalaştırma Projesine “sakıncalı değil” raporu düzenlenmiştir. 2012'de onaylanan bu proje için aynı yıl Kalyon İnşaat ilk çalışmalarına başlamıştır. 2012 yılında Tabiat Varlıklarını Koruma Bölge Kurulu Gezi Parkı yerine Taksim Kışlası’nın yapılma kararına, oy birliği ile ret kararı vermiş; ancak Tabiat Varlıklarını Koruma Yüksek Kurulu reddedilen projeye onay vermiştir (Ayata ve Çağlı, 2013: 1-4).

Yukarıda belirtilen idari süreçten sonra da yargısal süreç başlamıştır. Önce sit alanı olarak ifade edilen sonrasında Yayalaştırma Projesi kapsamında yıkılması planlanan Gezi Parkı yaklaşık 50 kişilik çevreci bir eylem olarak başlamıştır. Ancak sonrasında toplumsallaşmış ve siyasal taleplere bürünmüştür. Bu noktada, Gezi Parkı Eylemleri'ni sistematik bir biçimde açıklayan SETA'nın görüşlerine yer vermek faydalı olacaktır.

SETA, Gezi Parkı Eylemlerini Başlangıç (27-31Mayıs), Siyasallaşma (1-15 Haziran) ve Zayıflama Aşamaları (15 Hazirandan sonra) olarak sınıflandırmaktadır. Başlangıç Aşamasında, çevreci aktivistlerin barışçıl yöntemleri; Siyasallaşma Aşamasında eylemlerin toplumsallaşması ve 
hükümet karşıtlığı; Zayıflama Aşamasında sokak muhalefetinden barışçıl yöntemlere yönelme söz konusudur (SETA, 2013: 24).

Gezi Parkı Eylemleri birbirinden farklı kimliklerin, siyasi düşüncelerin, inançların, takımların hatta cinsiyetlerin bir arada dayanışma kültürünü yansıttığı önemli bir demokratikleşme hareketidir. Zira bu kadar farklılığın ortak paydada buluşabilmesi bu durumu açıklamaktadır. GENAR tarafından yapılan araştırmada eyleme katılan yurttaşların toplumsal sınıflarının birbirinden farklı olduğu gözlenmektedir. Araştırmaya göre, eylemlere destek verenlerin $\% 53,8^{\prime} \mathrm{i}$ maaşlı/ücretli bir işte çalışmakta, \%24,1'i öğrenci, \%10,8’i işsiz, \%6,4'ü ev hanımı, \%2,4’ü kendi işini yapmaktadır. Aynı şirket tarafından yapılan diğer bir araştırma ise, Türkiye'nin en büyük sorunun ne olduğu üzerinedir. Buna göre, eyleme katılanların \% 18,9'u özgürlük olmaması, \% 16,3 ayrımc1lık, eşitsizlik, adaletsizlik, \% 13,3 eğitim, \% 11'i işsizlik, \%10’u ekonomi \%8’i Recep Tayyip Erdoğan olarak değerlendirmiştir (Yeni Şafak, 2013).

Araştırmalar değerlendirildiğinde, eylemlere destek verenlerin hem sınıfsal açıdan birbirine benzemediği hem de toplumsal sorunlar bazında yüksek oranda aynı problemleri dile getirmediği gözlemlenmektedir. Ancak buna rağmen eylemlerin hayata geçirilmesinde aynı safta yer alabilmişlerdir. Bu noktada eylemlerinin neden ve nasıl toplumsallaştığı sorusu akla gelmektedir.

Erdemol'a göre siyasi katılımın gün geçtikçe ortadan kaldırılması, iktidarın kimi konulara el atarken büyük toplumsal itirazlarla karşılaşmaması ve buna dayanarak toplumsal meşruiyetin verdiği rahatlıkla topluma kendi meşrebi doğrultusunda çeki düzen verme çabası protestoların temel nedenidir (Erdemol, 2013: 14). Erdemol'un altını çizdiği alan aslında temsili demokrasinin yaşadığ 1 krizi yansıtmaktadır. Çünkü oy oranları siyasal iktidarın meşruiyetini tek belirleyen değildir.

İstanbul Bilgi Üniversitesi tarafından yapılan anket çalışmasına göre de Gezi Parkı Eylemlerine neden olan asıl konu Başbakan Erdoğan'ın otoriter tavrı olarak belirlenmiş ve eyleme destek veren katılımcıların protestoların sonunda beklediği en önemli şeyin "Özgürlüklere saygı" olduğu ifade edilmiştir (T24, 2013). 
Yukarıda bahsi geçen her iki anket çalışması da problemin kaynağını ve çözüm yolunu özgürlük ekseninde açıklamaktadır. Özgürlüklere saygının olmaması, muhatap kabul edilmeme ve atılan siyasi adımların seçilmiş iktidarın meşruiyetiyle açıklanması Gezi Parkı Eylemleri’nin çıkış noktası olarak belirir. Ancak bu eylemleri sadece özgürlük çerçevesinde değerlendirmek indirgemeci bir bakış açısını yansıtır. Bu nedenle, eyleme katılanlar ve siyasal iktidar arasındaki farklılıkların değerlendirilmesi gerekmektedir.

Ayata, farklılıkları kültürel temelde değerlendirmektedir. Ayata, Gezi Parkı Eylemleri'nin kültür çatışması olarak ele almakta ve çatışılan şeyin katılımcılara dayatılan ataerkil, buyrukçu, muhafazakar kültür ve siyaset olduğunu belirtmektedir (Kongar ve Küçükkaya, 2013: 37). Siyasal iktidarın bir toplum mühendisliği yapıp yapmadığı konusunda kanıtlanabilir bir veri olmadığından bu konu hakkında net bir fikir bildirmek doğru olmayacaktır. Ancak çalışma içerisinde farklı görüşler çerçevesinde değerlendirilecektir. Bu bağlamda eyleme destek verenlerin ve iktidarın süreci nasıl yorumladığına değinmek daha sağlıklı bir bakış açısı kazandıracaktır.

Gezi Parkı Eylemleri, siyasal iktidara yönelik tepkisini Başbakan Erdoğan üzerinden şekillendirmiştir. Zira Gezi Parkı Eylemleri’nin siyasallaşması ve iktidar karşıtlığı üzerinden gelişmesinde Başbakan Erdoğan’n yaptığı bazı açıklamaların da etkili olduğu gözlemlenmektedir. 1 Haziran 2013’te Gezi Parkı eylemcilerine "çapulcu” şeklinde seslenmesi bu noktada en önemli örnektir (Sabah Gazetesi, 02.06.2013). Çapulcu kavramı bu açıklamalardan sonra bir üst kimlik haline dönüşmüş ve Gezi Parkı Eylemleri'ne destek verenlerce tüm iletişim alanlarında yer almaya başlamıştır.

Siyasal iktidar açısından süreç değerlendirildiğindeyse; Erdoğan'ın Türkiye İhracatçılar Meclisi Genel Kurulu’nda yaptığı açıklamalar anlamlıdır. Bu kurulda Erdoğan, hükümetin attığı her adımın sorgusuz sualsiz lokal tepkilerle karşılaştığını, parlamenter sistemin gereği olarak sand1ğın belirleyiciliğini, bu eylemlerin ülkede gerilim yarattığını, gerilimin ana muhalefet partisi başta olmak üzere "aşırı uçlarca" desteklendiğini 
ifade etmiştir (Sabah Gazetesi, 01.06.2013). Erdoğan'ın genel tavrı siyasal kararların meşruiyetini sağlayan aygıtın seçimler olduğudur. Bu nedenle iktidar politikalarından duyulan rahatsızlığın sandıkta çözülmesinin parlamenter demokrasiye uygun olduğu vurgulanmış ve konuyla ilgili yargı kararına uyulacağının altı çizilmiştir. Ancak buna rağmen uslübunun sert ve ayrıştırıcı olması kitleleri tatmin etmemiştir.

Gezi Parkı Eylemleri'nin toplumsallaşması ve siyasallaşmasını daha iyi değerlendirebilmek amacıyla hareketin yapısal özelliklerine değinmek faydalı olacaktır. Bu çalışmada eylemler, yeni toplumsal hareketler olarak ele alınmıştır. Çünkü yeni toplumsal hareketlerin özellikleriyle benzeşen yönleri vardır.

Yeni toplumsal hareketler, modernitenin hegemonik biçimlenmeyle ortaya koyduğu türdeşleştirme ve nesneleştirme unsurlarına, özerklik ve özgürlük talepleriyle karşı durmuşlardır (Özdemir, 2013: 83). Küreselleşme süreci içinde değerlendirilen yeni toplumsal hareketlerin Gezi Parkı Eylemleri sürecinde etkin rol üstlendikleri söylenebilir.

Yeni toplumsal hareketlerin kültürel alana ve yaşamsal pratiklere odaklı olması siyasal bir talep olarak ele alınmalıdır. Çünkü "daha iyi bir yaşam talebi” içinde bu hareketlerin örgütlenmesi, çoğalması siyasetin sadece iktidar mücadelesi olarak anlaşılmasına yönelik tepkiyi ifade etmektedir (Yıldırım, 2012: 76). Gezi Parkı Eylemleri değerlendirildiğinde hükümetin attığı adımların yaşam tarzına müdahale olarak algılanması bu kapsamda değerlendirilebilir. İktidarın meşruiyetini belirleyenin sadece oy oranlarına indirgenmesi iktidara yönelik toplumsal muhalefeti doğurmuştur. Bu muhalefetin niteliği ise konjonktürden bağımsız değildir. Çünkü küreselleşmenin etkisiyle ulus devlet vatandaşlığının kimlik temelli uyarlamalara dönüştüğü yadsınamamaktadır. Daha iyi bir yaşam talebi, ileri demokrasi talebidir. Nitekim demokrasi taleplerinin belli aralıklarla gerçekleşen seçimlerle ifade edilmesi sınırlı bir katılımı yansıtmaktadır. Toplumun yaşadığı kentte söz sahibi olmak istemesi, belli bir demokrasi seviyesine ulaşıldığını da göstermektedir. Söz konusu talepleri sadece kentsel haklarla sınırlandırmak da doğru 
değildir. Zira bu talepler birbirinden bağımsız ve hareket lidersiz olması nedeniyle postmodernizmden izler taşımaktadır.

Yeni Toplumsal Hareket olarak Gezi Parkı Eylemleri ele alınacak olursa postmodern eğilimler dikkate alınmalıdır. Zira postmodern yaklaşımın karakteristik özellikleri; kısmilik, sadelik, görelilik, belirsizlik, benzerliklerin olmayışı, çoğulculuk, parçalanmışlık ve çok kültürlülük olarak ifade edilebilir (Barry, 2004: 217).

Postmodern siyasetin eleştiriye açık, tek doğruya değil herkesin kendi doğrularının varlığını kabul eden hoşgörülü bir anlayışta eleștirinin kamusal alana taşınabilmesi, demokratik bir siyaset ve kamusal tartışma alanına da zemin hazırlamaktadır (Çağlar, 2008: 381). Gezi Parkı Eylemleri de farklılıkların dayanışması ve zorlamayla mücadele etme biçimiyle bu niteliklere haiz görünmektedir. Gezi Parkı Eylemleri sonrasında da gözlemlenen mahalle toplantıları vb. zorlamayla mücadele yolu olarak adlandırılabilir. Bu bağlamda çalışmanın başında da ifade edildiği üzere kamusal kararların müzakere aracılı̆̆ıyla meşru bir zemine çekilmesi mümkündür. Mansbridge de müzakere sürecine bu yönüyle dikkat çekmektedir. Çıkar grupları, siyasal partiler, toplumsal akımlar, işyerleri, siyasal kolektiviteler arasındaki müzakereler "korunaklı özel alanların" farklı biçimleri olarak yorumlanmış ve bu müzakerelerde adaletin sağlanmasında demokrasilerin bu özel direniş alanlarını tanımaları ve desteklemeleri gerektiği üzerinde durulmuştur (Mansbridge, 1999: 91).

Müzakere ve dayanışmanın ortak payda oluşturduğu noktasında Gezi Parkı Eylemleri, Türkiye açısından önemli bir örnektir. Toplumsal algılarda "aşırı uç" olarak nitelendirilen sosyalist örgütlerle dini yönü ağır basan örgütleri "yeryüzü sofrası" adı altında iftar sofrasında buluşturabilmiş olması bu durumu kanıtlar niteliktedir (Ayata ve Çağlı, 2013: 18). Ayrıca Gezi Parkı Eylemleri Türkiye’nin pek de alışık olmadığ şiddeti, kişileri ve olayları ironik biçimde ele almıştır. Başbakan Erdoğan ile görüşen Necati Şaşmaz’ın “Türkiye'ye nazar değdi.” açıklamasından sonra dev bir nazar boncuğu afişinin AKM'ye asılması bu durumun güzel bir örneğidir. 
Özetle, Gezi Parkı Eylemleri, demokrasinin belli aralıklarla sandığa giderek seçim yapmaktan daha ileri bir boyut taşıdığına yönelik talebin ifadesidir. Bu nedenle siyasal iktidarın kamusal kararlar alırken toplumun taleplerini dikkate alması, onun meşruiyetini güçlendirmektedir. Dolayısıyla çatışmadan ziyade uzlaşma ancak müzakere süreciyle mümkündür. Türkiye demokrasisinin yaşadığı bu krizi daha iyi anlayabilmek için kırılma noktalarının tespit edilmesi önem taşımaktadır.

\section{Gezi Parkı Eylemleri'ni Hazırlayan Kırılma Noktaları ve Temsili Demokrasi Krizi}

Gezi Parkı Eylemleri “Taksim Yayalaştırma Projesi”ne karşı çevreci bir direniş olarak başlasa da eylemleri sadece çevrecilikle ilişkilendirmek indirgemeci bir yaklaşımı yansıtır. Çevreci kaygılar, bütünün bir parçasını yansıtmaktadır. Ancak kısa sürede siyasallaşan Gezi Parkı Eylemleri diğer toplumsal paradigmalardan bağımsız değildir. Hükümetin politikaları, Başbakan Erdoğan'ın tavrı ve siyasi duruşu, seçmeni olmayan kitleleri rahatsız etmiştir.

Özel hayata müdahale kapsamında değerlendiremeyeceğimiz eleştirilerden biri de Üçüncü Köprü’nün ismidir. İstanbul'da yapımına başlanan Üçüncü Köprü’nün ismi temel atma törenlerinde Yavuz Sultan Selim olarak belirlenmiştir. Yavuz Sultan Selim Osmanlı Devleti’nin yükselme dönemi padişahı olmakla birlikte tartışmalı bir padişahtır. Tarihsel tartışmaların ötesinde Yavuz Sultan Selim ismi Aleviler başta olmak üzere toplumun önemli bir kesimi tarafından benimsenmemiştir. $\mathrm{Bu}$ isim devletin tarihsel olaylarda taraf olduğu izlenimini yaratmıştır. Devletin taraf olması ise iktidara karşı güvensizlik oluşturmuş ve toplum içinde kutuplaşma yaratmıştır.

Gezi Parkı Eylemleri'nde dile getirilen muhatap kabul edilme talebi tanınmayı içermektedir. Siyasal tarafsızlık devletin herhangi bir iyi anlayışını vatandaşlara dayatmamasını içermekte ve "tarafsız devletin görevi iyi insan yaratmak değil, insanların farklı iyi anlayışlarını realize edebilecekleri ortamı hazırlamaktır" (Aktaran Arslan, 2005: 31). Dolayısıyla devletin kamusal kararlarda bir kimlik edinmesi, o kimliği 
paylaşmayan bireylerin politikaları benimsememesine yol açar. Bu durum ise meşruiyet krizinin siyasal hayata yansımasıdır. Temsili demokrasi ve meşruiyet krizi alt başlıklarda daha detaylı tartışılacaktır.

\subsection{Atatürk, Ulusal Değerler ve \\ Devlet Geleneği'nde Temsili Demokrasi Krizi}

2002 Seçimlerinden itibaren AK Parti’nin iktidara gelmesi pek çok kişi tarafından kaygıyla izlenmiştir. AK Parti’nin muhafazakar yönü, Devlet geleneğiyle tezat yapısı ulusal değerlerden taviz korkusunu beraberinde getirmiştir. AK Parti’nin siyasal duruşunu ve geleneğine değinmek konuyu aydınlatmak açısından anlamlıdır.

AK Parti, Milli Görüş Hareketi geleneğinden gelmekle birlikte bu hareketten farklılaşan yönleri Türkiye'de merkez sağı oluşturmasına ve oy oranlarının her seçimde artmasına neden olmuştur. Parti ve gelenek arasındaki farklılıkları AK Parti açısından Bölükbaşı (2012: 179-180) şu şekilde özetlemektedir:

1.Radikal İslamcı çizgiden ayrılma ve daha ılımlı bir muhafazakar demokrat kimlik belirlemesi,

2.Post İslamcı çizgide Kemalizm’in eleştirilmesi ancak reddedilmemesi,

3.Dinin politik rejimde değil gündelik hayatta olması hedefi,

4.Devletçi millici ekonomik politikadan ziyade neo-liberal anlayışı benimsemesi,

5.Moderniteyle uyumu, batı ile ittifak yapabilmesidir.

Bu bağlamda partinin İslamcı çizgiyi revize ederek İslam ve demokrasiyi birleştirebilmesi merkez sağın temsilcisi olmasını kolaylaştırmıştır.

AK Parti iktidarı devlet geleneğinde ezber bozan pek çok düzenleme yapmıştır. Askeri vesayetin kaldırılması gibi demokratik adımlar atılmış olsa dahi toplumsal meşruiyete dayanmayan ve henüz bir sonuca kavuşmamış açılımlar söz konusu olmuştur. AK Parti hakkındaki kaygıların nedenlerinden en önemlisi Muhafazakar Demokrat kimliğini açıkça ifade etmesinden kaynaklanmaktadır. Muhafazakar demokrasi, 
28 Şubat'ın ardından İslamiyet'in sosyal ve ekonomik yapılarını sosyal alanda temellendirilmesi ve İslamcılığın yıkıcı niteliğinden arınma noktasında AK Parti'nin bu kimliği benimsemesi olarak ifade edilebilir (Bakan ve Arpac1, 2012: 137).

AK Parti’nin muhafazakarlık kavrayışı hakkında Doğanay, "merkezi otoritenin gücünü, siyasal birliği, seküler toplumsal erdemleri" vurgulayan İngiliz muhafazakarlığı karşısında, "yerel otoriteleri, cemaatçiliği, dinsel değerleri” öne çıkaran Amerikan muhafazakarlığına yakınlaşmakta olduğunu belirtmektedir (Doğanay, 2007: 72). Doğanay bu bağlamda din ve geleneklerle aktarılan ahlaki değerlerin, topluluğun "ortak iyisi"ni güvenceye almanın başlıca yolu olduğunu ifade etmektedir (Doğanay, 2007: 72). Dolayssıyla “ortak iyi”nin belirlenmesinde din etkili bir araç olarak ön plana çıkmaktadır. Toplumun kimlik olarak muhafazakarlaştığı noktasında çıkarılabilen bir sonuç da SETA tarafından yapılan araştırmada ortaya çıkmıştır.

Araştırmaya göre, kişilerin kendilerini nasıl tanımladıkları sorulduğunda 1999 yılında \%20.4'ü Türk, \%35.7'si Müslüman, \%34.1’i Türkiye Cumhuriyeti Vatandaşı olarak tanımlarken 2006 yılında; \%19.4'ü Türk, \% 44.6’sı Müslüman, \%29.9’u Türkiye Cumhuriyeti Vatandaşı olarak tanımlamaktadır (Çarkoğlu ve Toprak, 2006: 41). Geçen süre göz önüne alındığında kişilerin büyük bir çoğunluğunun kendisini dini referansla tanımladığı gerçeklik taşımaktadır.

Açıel, AK Parti Hükümetinin yeni bir toplum mühendisliği uyguladığını ifade ederek süreci "Yeni Muhafazakarlık” şeklinde tanımlamaktadır. Yeni Muhafazakarlığın devletle toplumu birleştirmesinde iktidarın "sivil toplumcu yaklaşımları" terk ederek yeni hakikatler ürettiğine değinmiş ve Türkiye'de daha önceki dönemlerde jakoben politikaları eleştiren muhafazakâr geleneğin, kendisinin inisiyatif aldığ 1 "yukarıdan muhafazakârlaşma” sürecini başlattığını ifade etmiştir (Açıkel, 2012: 16).

Türkiye'de muhafazakârlaşma olgusu özellikle Atatürkçü ve laik kesim tarafından kaygıyla değerlendirilmiştir. Zira devletin temel niteliğinden bağımsız olmayan laiklik, modernizme atıf yapmakta ve yol 
göstermektedir. Din ve vicdan özgürlügüünün teminatı olan laiklik, devletin dini olmaması düşüncesini kapsamaktadır.

Siyasal iktidarın kendisini "Muhafazakâr Demokrat" kavramıyla tanımlaması, Kuran Kurslarını yaygınlaştırması, eğitim kurumlarında zorunlu din derlerinin olması, Cumhuriyetin kuruluş döneminin sürekli eleştirilmesi AK Parti seçmeni olmayan ve kendisini Atatürkçü olarak tanımlayan yurttaşları rahatsız etmiştir.

Gezi Parkı Eylemlerine destek veren katılımcıların \% 33.5’i kendisini Atatürkçü, \%16'sı özgürlükçü, \% 12'si sosyalist, \% 8.9'u sosyal demokrat, \% 8.4'ü demokrat, \%6.1'i laik olarak tanımlamaktadır (Yeni Şafak, 2013).

$\mathrm{Bu}$ açıklamaların karşısında yapılan başka bir araştırmada ise toplumun muhafazakarlaşmadığı sonucu ortaya çıkmıştır. Açık Toplum Vakfı ve Boğaziçi Üniversite'sinin desteğiyle yapılan araştırma sonucunda muhafazakârlığın uç noktalardan ortalara çekildiği belirlenmiştir. Araştırma sonucunda ibadet edenlerin sayısında, giyim tarzından ve alkol alınmasından rahatsızlık oranlarında 2006'dan 2012'ye geçerken düşüş gözlendiği, özgürlük taleplerinin yükseldiği açıklanmıştır (www.t24.com,13.03.2014).

Yukarıda yer alan açıklamalar Türkiye’nin muhafazakârlaşması konusunda ortak fikri paylaşmamaktadır. Dolayısıyla kesin bir yargıya varmak zor görünmektedir. Ancak bu konu iktidarın muhafazakâr kimliğini açıkça ifade etmesinden ve devlet geleneğinde farklılaşmalardan rahatsızlığın yansıması olarak değerlendirilebilir.

İktidara yönelik toplumsal muhalefetin ve devlet geleneğindeki farklı uygulamalara verilen tepkilerden biri Anitkabir ziyaretleridir. Anitkabir'i 10 Kasım 2012'de 413 bin 568 kişi ziyaret ederken 2013'te 1 milyon 89 bin 615 kişi ziyaret etmiştir. Genelkurmay Başkanlığ 2012 yılına oranla 2013'te toplam ziyaretçi sayısının üç katına ulaştığını açıklanmıştır (Milliyet, 23.01.2013). Devlet zirvesinin ulusal bayramlara katılmaması üzerine Anıtkabir ziyaretleri ulusal değerlerin korunması için atılan bir adımdır. 


\subsection{Kent Kültürü ve}

\section{Çevreci Kaygılar Çerçevesinde Temsili Demokrasi Krizi}

Kent çeşitli etnik grupları, sosyal grupları, ayrı kültür ve inanç sistemlerinden insanları bir arada barındıran heterojen bir sosyal gruptur (Görmez, 1997: 10). Kentleşme ise, sanayileşme ve ekonomik gelişmeye koşut olarak kent sayısının artması ve kentlerin büyümesi, toplum yapısında artan oranda örgütlenme, işbölümü ve uzmanlaşma yaratan, bireylerin davranış biçimlerini değiştiren nüfus birikimi süreci olarak tanımlanmaktadır (Keleş, 2004: 19). Bu anlamda kentleşme süreci çeşitli unsurların etkisiyle geleneksel davranış ve tutumları etkisizleştirerek, yerine yeni tutum ve davranış biçimlerinin sergilendiği bir kent kültürü oluşturmaktadır.

Keleş kentlileşme kavramını, kentleşme akımı sonucunda toplumsal değişmenin insanların davranışlarında ve ilişkilerinde, değer yargılarında, tinsel ve özdeksel yaşam biçimlerinde değişiklikler yaratma süreci (1998: 71) olarak tanımlamaktadır. Bu durumda, kentlileşmenin; siyasal tutum ve davranışlar, toplumsal değerler, örgütlenme biçimleri, bilinçlenme, dini tutum ve davranışlar, hak arama yöntemleri ve farklılıkların ifade edilmesi üzerinde etkiye sahip olduğunu söyleyebiliriz.

Bir kente girildiğinde, o kentin tarihini ve kültürünü yansıtan yap1lar, eğlence ve dinlenme alanları, tarihi yapısı, mimari özellikleri, halkın giyimi kuşamı vs. kent kültürü hakkında bize ipuçları verir. "Bu bağlamda kent, gelenek ve göreneklerin, örgütlü tavır ve görüşlerin toplandığı yerdir. Kültürler kentte doğarlar, kentte yaşarlar ve kente katkı sağlarlar. Bu niteliğiyle kentler, belli bir kültürü simgelemektedirler. Kentsel mekanlar, toplumların yapısı ve sanat anlayışına göre farklılık göstermektedir. Bu farklılıkları doğuran yine toplumun sosyal yaşamı, kültürü, ekonomik yapısı, teknolojisi, politik yapısı ve sanat anlayışının fiziki mekana yansımasıdır” (Uçkaç, 2006: 31).

Kamusal alanın en önemli niteliği tüm vatandaşlara açık olmasıdır. Kamusal alan, sosyal ve politik sorunların çözümü amacıyla kişiler arasında değerler ve ölçütler üzerinde anlaşmaya varılma imkanının bulunduğu yaşam alanıdır. Kültürü meta biçimine getiren ve onu tartışılmaya uygun bir yapıya dönüştüren kamusal topluluk, dışa kapalı 
olmayan bir nitelik kazanmaktadır (Habermas, 2012: 107) . Habermas'ın ortaya koyduğu kamusal alan, bireylerin kendi görüşlerini açık platformda özgürce tartıştıkları bir platformdur. Habermas, yurttaşların eşit bir biçimde kamusal alanda kendilerini ilgilendiren konularda rasyonel ve eleştirel bir biçimde tartışabilmesini demokrasinin temeli olarak anlatır. Habermas’n kamusal alan görüşü müzakereci demokrasi kuramı ile bir bütünlük arz eder. Eşit, özgür yurttaşlar her türlü konuda kamusal müzakere yürütebilirler.

Rawls' da kamusal alan, kamusal uzlaşma temelinde tesis edilmiştir; bu alanda belirleyici olan ise kamusal akıldır. Kamusal akıl, liberal toplumun kendi tarihinden taşıyıp getirdiği liberal ilke ve değerlerden oluşan liberal kültürdür. Kamusal akıl, liberal bir toplumda temel anayasal, siyasal, iktisadi kurumlar ve prosedürlerin kurucu normatif ilkesidir (Denli, 2006). Rawls, kamusal aklı, demokratik bir toplumda yasa yapmak ve anayasa değişikliğine gitmek bakımından, "kolektif bir bütün olarak birbirleri üzerinde nihai siyasal ve zorlayıcı güç kullanan eşit yurttaşların" aklı olarak tanımlar ve işlevselliğini siyasal alanla s1nırlandırır (Karadağ, 2006: 23).

Modern demokrasi teorilerinde kamusal alana ilişkin saptamalar, daha çok kamusal alanın kimler tarafından, nasıl paylaşılması, katılım süreçlerinin ne olması gerektiği ve kamusal alanda yapılan tartışmaların nasıl sonlandırılması üzerinde yoğunlaşmaktadır. Demokrasi teorisi, karar verme süreçlerinde hesap verilebilirlik ve sorumluluklar üzerinde dururken, kamusal alan teorileri, bu süreçlerdeki kamusal iletişimin rolü hakkındadır (Eren, 2005: 102-109). Gezi Parkı Eylemleri'nin arka planında yer alan nedenlerden biri de tarihsel olarak önem taşıyan kentsel mekanların "Kentsel Dönüşüm Projeleri”yle yıkılması olmuştur. Emek Sineması, İnci Pastanesi ve Sulukule önemli örnekleri oluşturmaktadır.

\section{3. Özel Hayata Müdahale Noktasında Temsili Demokrasi Krizi}

Gezi Park Eylemleri'nde vurgulanan en temel talep demokrasi talebidir. Demokrasi talebi siyasal iktidara oy veren/vermeyen yurttaşların 
değer ve düşüncelerinin dikkate alınması noktasında gerçekleşmiştir. Demokrasi talepleri kamusal kararlara katılamayan farklı toplumsal s1nıfların kendilerine özgü duyarlılıklarıdır. Bu talepler genel olarak kimlikle ilgili olsa da farklıklara saygı gösterme temelinde şekillenmiştir. Farklılıklara saygı düşüncesi dayanışma kültürünü de ortaya çıkarmıştır.

Çaha’nın belirttiği üzere, demokrasi başta siyasal farklılaşma olmak üzere, ideolojik, kültürel, etnik, cinsiyet veya yaşam felsefesine dayalı her türlü farklılığı zenginlik olarak kabul etmektedir (Çaha, 2005: 360). Bu bakış açısıyla düşünüldügünde, demokrasi farklılıkları kapsayan ve hiçbir farklılığı dışlamayan bir sistemdir. Dolayısıyla demokratik yönetimin kriz yaşamaması için farklılıkları bütünün parçası olarak görmek ve söz hakkı tanımak gereklidir. Her bireyin uzlaştığı kamusal kararlara ulaşmak demokrasi pratiğinde zor olsa da bireylerin özel alanlarına müdahale noktasında kararlarına başvurmak bu pratik için gereklidir. Zira kamusal alan toplumsal ve siyasal alana işaret ederken özel alan toplumsal ve siyasalın dışındadır. Dolayısıyla siyasal kararları içermemesi gerekir. Siyasal iktidarın özel hayata müdahale noktasında yasal düzenlemeleri olduğu gerçeklik taşısa da alt başlıklarda tartışılacak olan tüm konularda yasal düzenleme olduğunu söylemek gerçeklik taşımamaktadır.

\section{Kürtaj Yasa Tasarısı}

Ataerkil toplum yapısının bir sonucu olan kadına yönelik şiddet, ülkemizin en ciddi problemlerinden biridir. Kadına yönelen bu şiddeti sadece fiziksel saldırı olarak değerlendirmek ise eksik bir yaklaşımı yansıtır. Kadına yönelik şiddetin bir yönü de kadının kendi bedeni üzerinde söz söyleme hakkını engellemektir. Bu nedenle kamuoyunda "Kürtaj Yasası" olarak bilinen "Üreme Sağlığı ve Çocuk İstismarı Yasa Tasarısı" kadın bedenine yönelik bir şiddet olarak değerlendirilmiştir.

Söz konusu yasa tasarısı konusunda en önemli eleştiri kadınların üreme ve istemli düşük haklarının geri alınması üzerinedir. Kürtajın sadece devlet hastanelerinde yapılması, kürtaj sayısında artışların tasarıya dayanak oluşturmaması, doğum kontrolünün erkeklere de 
uygulanabileceği ve bu kararı kadınların vermesi gerektiği konuları yapılan eleştirinin kaynaklarıdır (www.ttb.org.tr. 28.01.2014).

Türkiye 1985 yılında "Kadına Karşı Her Türlü Ayrımcılığın Önlenmesi Uluslararası Sözleşmesi’ni (CEDAW)” imzalamıştır. CEDAW Komitesi'ne göre, "Taraf devletler, kadınların, doğurganlıklarının kontrolüyle ilgili uygun hizmetlerin olmaması nedeniyle onların yasadışı kürtaj gibi güvenli olmayan tıbbi uygulamalar arayışına girmek zorunda kalmalarına engel olmalıdır" (www.unicef.org.28.01.2014). Bu maddeye göre, kadınların gebelik dönemindeki hizmetlerden sağlıklı bir şekilde faydalanması devletin görevidir. Gebelik dönemi bebeğin doğması kadar ceninin rahimden tasfiyesini de içermektedir.

Yasa tasarısı kürtaj hakkını engellediği gerekçesiyle başta sağlıkçılar olmak üzere pek çok kadın STK'ları tarafından eleştirilmiş ve "Bedenime Dokunma” eylemlerine yol açmıştır. Söz konusu yasa tasarısı hakkında Türk Tabipler Birliği; kürtajın sadece devlet hastanelerinde ve uzman kişilerce yapılmasının bu hizmete ulaşımı engellediği, kürtajın bir doğum kontrol yöntemi olarak algılandığı, "cinayet” olarak nitelendirildiği ve 10 hafta ve daha kısa süreli cenine uygulanmasının, uluslararası alandan kısa süreli olması nedeniyle eleştiride bulunmuştur (www.ttb.org.tr. 28.01.2014). Zira toplumda yaratılan yargi, rahim tasfiyesinin cinayet olarak değerlendirilmesi ve bu hizmetin sağlıksız koşullarda gerçekleştirilmesi durumunda devletin sorumluluk almayacăğdır. Dönmez ise kürtajı hukuksal açıdan değerlendirmekte 10 haftadan uzun gebeliklerin kürtajla sonuçlanması durumunda hapis ve para cezalarına dikkat çekmektedir (Dönmez, 2007: 112).

Yasa tasarısının belki de en çok tartışılan kısmı kürtajın doğum kontrol yöntemi olarak ifade edilmesidir. Ancak bu uygulama doğum kontrol yöntemi değil istenmeyen gebeliğin sona erdirilmesidir. Bu bağlamda Dünya Sağlık Örgütü’nün araştırmalarına değinmek açıklayıcı olacaktır.

Dünya Sağlık Örgütü’nün verilerine göre dünyada her yıl, 210 milyon civarında gebelik meydana gelmekte, bunların yaklaşık 1/3'ü istenmeden oluşmaktadır. Dünyada meydana gelen gebeliklerin 46 milyonu isteyerek düşükle sonlanmaktadır. Yasaklamalar nedeni ile düşüklerin 
19 milyonu güvenli olmayan koşullarda gerçekleşmektedir. Güvenli olmayan düşüklere bağlı olarak dünyada her sekiz dakikada bir kadın ölmektedir. Türkiye'de 10 haftaya kadar kürtajın serbest bırakılmasından bu yana, kürtajlar 3 kat, anne ölüm hızı 6 kat azalmış, Modern Aile Planlaması Yöntem Kullanımı 2 kat ve Kadınların Yaşam Süresi 14 yıl artmıştır (www.tjod.org.28.01.2014).

Veriler incelendiğinde istenmeyen gebeliklerin kürtajla sonlandırılmasında yasal düzenlemelerin önemi büyüktür. Bu noktada kürtaj hakkının kullanılabilmesi için sadece devlet hastanelerinin yetkilendirilmiş olması bu hakka ulaşmayı engellemekte ve kürtajın güvenli olmayan yerlerde yapılması sonucunu doğuracaktır. Bu nedenle devlet kadının bedeni üzerindeki haklarını kullanmasına yardımcı olmalı ve uygulamayı taahhüt ettiği CEDAW’’ hayata geçirmelidir.

\section{b. Alkol Düzenlemesi}

Tütün Mamulleri ve Alkollü İçkilerin Satışına ve Sunumuna İlişkin Usul ve Esaslar Hakkında Yönetmelikte Değişiklik Yapılmasına Dair Yönetmelik, Resmi Gazete'de yayımlanarak 18.09.2013 tarihinde yürürlüğe girmiştir.

$\mathrm{Bu}$ düzenlemeyle tütün mamulleri ve alkollü içkiler hakkında genel olarak 18 yaşın altındakilere satılmaması, sunulmaması bu kişilerin bu alanla ilgili işlerde istihdam edilememesi, alkollü içkilerin 22.00 ile 06.00 saatleri arasında perakende olarak satılamaması, pek çok yerde (eğitim kurumu, dershane, ibadethane vb 100m yakınında) satışının ve reklamlarının yapılamaması gibi yenilikler söz konusu olmuştur (Sabah Gazetesi, 28.01. 2013).

Alkol kullanımında yaş sınırı uygulanması elbette doğru bir adımdır. Ancak kamuoyunda en çok tartışılan/onaylanmayan durum alkollü içkilere ulaşma saatidir. Devletin alkol kullanımını kontrol etmesi noktasında bu düzenleme bireylerin hangi saatte hangi içeceklere ulaşmasını kontrol etme anlamına gelmektedir. Saat 22.00 'den önce satışı yapılabilen alkollü içkiler 22.00 'den sonra daha mı zararlıdır sorusunu 
gündeme getirmektedir. Bu noktada Türkiye'nin alkol tüketimi konusunda "problemli ülke" olup olmadığını incelemekte fayda vardır.

Türkiye'de alkol tüketim oranları konusunda KONDA Genel Müdürü şunları ifade etmiştir (Milliyet, 28.01.2013):

“Sofuların yüzde 9'u, dindarların yüzde 11'i, 'inançlyıım' diyenlerin yüzde 41'i, inançslzların da yüzde 65'i alkollü içki tüketiyor. Alkol sorunu yok; düzenli içen 3 milyon 600 bin kişi var. Rakamlara baktığımız zaman, "Türkiye'de bir alkol problemi var" demek mümkün değil."Inançl-yım" diyenlerin yüzde 41'i (yaklaşık 7 milyon 500 bin); inançsızların da yüzde 65'i (yaklaşık 740 bin)".

Araştırmalar gösteriyor ki Türkiye alkolü yoğun olarak tüketen ve bununla mücadele etmesi gereken ülkelerden biri değildir. Bu nedenle yapılan düzenleme alkol alma özgürlügüne karşı atılmış bir adımdır. Açık alanlarda alkol tüketiminin engellenmesine yönelik genelge hakkında bir vatandaşın açtığı davada karar iptal edilmiş ve Anayasa’nın 13.maddesine aykırı olduğu ifade edilmiştir (Hürriyet, 28.01.2013).

Alkol tüketmek /tüketmemek-tıpkı kişilerin ne yiyip/yemeyeceği gibi- kişinin kendi karar verebileceği özel alanı işaret etmektedir. İdeal toplumun siyasal iktidarın ideolojisine ve değerlerine göre şekillendirilmesi demokratik düşünceye denk düşmemektedir.

\section{Üç Çocuk Talebi}

Gezi Parkı Eylemlerinde kullanılan pankartlarda ve dövizlerde yer alan göndermelerden birisi de Başbakan Erdoğan’in katıldığı törenlerde dile getirdiği "En az 3 çocuk" talebiydi. Başbakan Erdoğan birinci ve ikinci çocuğun iflas üçüncü çocuğun yerinde olduğunu ifade etmiştir (www.cnnturk.com. 28.01.2013). Erdoğan’n bu ifadesi Türkiye nüfusunun yaşlanmaya başlaması yönündeki kaygıyla açıklanmıştır. Türkiye nüfusunun yaşlanması TUİK verilerine göre haklılık taşımaktadır.

2013 TUİK verilerine göre demografik göstergelerdeki mevcut eğilimler devam ettiği takdirde Türkiye nüfusu yaşlanmaya devam edecektir. 2012 yılında yaşlı nüfus olarak tabir edilen 65 yaş ve üzerindeki 
nüfus 5,7 milyon kişi, bunların toplam nüfusa oranı \%7,5'tir. 2023 yılına gelindiğinde bu nüfusun 8,6 milyon kişiye, oranı ise $\% 10,2$ ye yükseleceği tahmin edilmektedir (http://www.tuik.gov.tr. 28.01.2013).

Nüfusun yaşlanması sosyal ve ekonomik sorunlara neden olmaktadır. Bu durum çalışma çağındaki nüfusun azalmasına ve yaşlanmasına, emekli sayısında, sağlık harcamalarında bir artışa neden olarak kamu harcamalarını artırmaktadır (Gündoğan, 2001: 96). Dolayısıyla nüfusun yaşlanması Türkiye açısından gelecekte olumsuz bir durum yaratabilir. Ancak ekonomik büyüme ve kalkınma açısından nüfus tek belirleyici değildir.

3 çocuk talebinin Gezi Parkı Eylemleri'nde muhalefet yaratması açılamanın sosyo-ekonomik boyutuyla ilgili değildir. Asıl eleştirilen konu bireylerin çocuk yapma/ yapmama iradesinin Başbakan Erdoğan tarafından yönlendirilmesidir. Eyleme destek verenler bu açıklamayı "Başbakan'ın yatak odasına karışması” bağlamında özel hayata müdahale noktasında değerlendirmişlerdir.

Ancak Başbakan Erdoğan’ın dile getirdiği kaygının, devlet eliyle bir zorlamaya dönüştürülmediği de hatırlanmalıdır. Zira bu konuda bir yasa yapılmamış ancak teşvik edici düzenlemelerin yapılabileceği ifade edilmiştir. Dolayısıyla yapılan açıklamanın şimdilik bir dilekten ibaret olduğu unutulmamalıdır.

\section{Toplantı ve Gösteri Yürüyüşü Düzenleme Özgürlüğü}

Temel hak ve özgürlükler içerisinde yer alan Toplantı ve Gösteri Yürüyüşü Düzenleme Özgürlüğü, 1982 Anayasası̉nın 34.maddesinde şu şekilde düzenlenmiştir: "Herkes, önceden izin almadan, silahsız ve saldırısız toplantı ve gösteri yürüyüşü düzenleme hakkına sahiptir. Toplantı ve gösteri yürüyüşü hakkı ancak, millî güvenlik, kamu düzeni, suç işlenmesinin önlenmesi, genel sağlığın ve genel ahlâkın veya başkalarının hak ve özgürlüklerinin korunması amacıyla ve kanunla sınırlanabilir. Toplantı ve gösteri yürüyüşü düzenleme hakkının kullanılmasında uygulanacak şekil, şart ve usuller kanunda gösterilir." 
Bir anayasal hak olan Toplantı ve Gösteri Yürüyüşü Düzenleme Özgürlügü, devlet-birey ilişkilerinde demokratik talepleri ifade etmenin yoludur. Bireylerin aynasal hakkı olan Toplantı ve Gösteri Yürüyüşü Düzenleme Özgürlügünün devlet tarafından da desteklenmesi demokratik yönetimleri güçlendirmektedir. Çünkü bu durum bireylerin kendilerini ifade etme biçimidir ve Gezi Parkı Eylemleri Toplantı ve Gösteri Yürüyüşü Düzenleme Özgürlüğü kapsamında ele alınmalıdır.

Ancak Gezi Parkı Eylemleri süresince mülki idare ve kolluk kuvvetleri, Toplantı ve Gösteri Yürüyüşü Düzenleme Özgürlügü̉nü kısıtlamıştır. İçişleri Bakanlığı’nın verilerine göre 81 ilin 79'unda Gezi Parkı Eylemlerine katılım olmuştur. Gezi Parkı protestoları sürecinde yaklaşık 2.5 milyon insanın eylemlere katıldığı, bu eylemlerde yaklaşık 4 bin 900 eylemci "şüpheli" konumunda gözaltına alındığ 1,600 'den fazla polisin, 4 bine yakın eylemcinin yaralandığı, 6 kişinin öldüğg̈ belirlenmiştir. $\mathrm{Bu}$ süreçte toplam zarar 140 milyon TL'dir (Radikal Gazetesi, 23.06.2013).

Bakanlığın açıklamaları doğrultusunda, anayasal hak olan toplantı ve gösteri özgürlüğüne izin verilmemesi maddi ve manevi kayıplara neden olmuştur. Bu özgürlük aynı zamanda demokratik talepleri ifade ettiği için önem taşımaktadır. Siyasal kararların sorgulanabilmesi, muhalefetin oluşması ve kamuoyunun fikirlerine başvurulması yönetimlerin meşruiyetini sağlamlaştıran adımlardır. Gezi Parkı Eylemlerinde yaşam hakkı başta olmak üzere, polisin tazyikli su ve biber gazını birincil müdahale aracı olarak kullanması, insan hakları ihlallerine yol açmıştır (İHD, 2013: 5). Ayrıca Sağlık Bakanının Gezi Parkinda yaşanan müdahaleler sonrasında acil sağlık hizmeti sunan doktorlar hakkında soruşturma açılacağını ifade etmesi, Çağlayan Adliyesi’nde avukatlara müdahale gerçekleşmesi de çalışma hakkını zedelemiştir. Bu durum, toplumsal kutuplaşmayı siyasileştirirken demokrasi düşüncesinin de sorgulanmasına neden olmuştur.

İnsan hakları ihlallerinin yaşanması dünya basınında da yer almıştır. El Cezire muhabiri biber gazını ve etkilerini ele alırken BBC masum bir çevreci hareketin hükümet karşıtı gösterilere dönüştügünü, polis müdahalesinin Uluslararası Af Örgütü ve ABD tarafından kınandığını, 
Guardian Gazetesi süreci “Türk Baharına” benzettiğini, Financial Times alkol yasağının tetikleyici olduğunu dile getirmiştir (Radikal Gazetesi, 31.05.2013). Dünya basınına sürecin yansıması elbette bu kadar değildir. Dünyanın pek çok ülkesi farklı biçimlerde eylemleri duyurmuşlardır. Ancak genel olarak eylemler çevrecilikle ilişkilendirilmiş ve polis müdahalesi eleştirilmiştir.

\section{Bir Çözüm Önerisi Olarak Müzakereci Demokrasi}

Müzakereci demokrasi yaklaşımı liberal demokrasinin yaşadığı meşruiyet krizini kabul eden ve bu krize çözüm yolları arayan bir yaklaşımdır. Krize sunulan çözüm ise; farklı kimliklerin siyasal ve sivil alanda müzakere ve diyalog sürecini yaşamalarıdır.

Müzakereci demokrasi yaklaşımına göre ortak paydaya ulaşmak için iletişim ve etkileşim ön plandadır ve müzakereci demokrasi yaklaşımı bireylere eşit söz hakkı tanıyarak demokrasi krizinin aşılacağını savunur (Ed.Bican, 2008: 116). İletişim ve etkileşim sürecinin bireyleri ve toplumsal kimlikleri uzlaşmaya kavuşturacağının altını çizer. Bu bağlamda herkesin söz söyleme ve eşit temsilini ön kabul olarak görür.

Siyasal kararlara katılım, "tanınma" ve "farklılık" politikasını gerektirmekte ve tanınma politikası demokrasilerin varlık nedenini oluşturmaktadır (Aktaran Aslan, 2005: 31). Bu paradigmaya göre, siyasal katılımın yüksek olması hem farklılıkların temsil edilmesini sağlamakta hem de demokrasiye meşruluk kazandırmaktadır.

Türkiye'de sivil ve siyasal kararların alınmasında ve hayata geçirilmesinde toplumun talepleri ve hassasiyetleri göz önüne alınmış olsaydı, iktidara yönelik tepkiler Gezi Parkı Eylemleri'ne yol açmayabilirdi. Zira bu kararlara yönelik girişimler ve protestolar kararların uygulamasından önce dile getirilmiştir. Bu tepkiler karşısında iktidar çoğunlukçu bir demokrasi anlayışını benimsemiştir.

$A B D$ ve İngiltere'de başlayan "İşgal Et" hareketlerinin Gezi Parkı Eylemleri'yle benzer yönleri vardır. İşgal Et hareketi yeni toplumsal hareket olarak nitelendirilen, farklı taleplerin birleştirildiği, kendiliğindenci ve hiyerarşik bir örgütlenmeye sahip olmaması yönüyle Gezi Parkı 
Eylemlerine benzemektedir. Ayrıca "yöneten azınlığın kapalı kapılar ardında aldığı kararları dünyanın geri kalanına dayatmalarına karşı” (Yıldırım, 2012: 239) işgalci bir eylem olarak devam etmiştir. Gezi Parkı Eylemleri de siyasal kararlara katılma talebi açısından -her ne kadar ortaya çıkış amacı farklı olsa da- bu eylemlere benzemektedir.

Toplumsal muhalefeti oluşturan bireysel talepler Gezi Parkı Eylemleri aracılığıyla kamusal alana aktarılmış ve Gezi Parkı Eylemleri farklı toplumsal kimliklerin ve değerlerin diyalog kurabileceğini göstermiştir. Habermas’a göre, demokratik yönetim bürokratik modern devletin yalnızca hukukun üstünlüğü ilkesiyle denetlenmesi anlamına gelmemelidir. Aynı zamanda yatay denetimi sağlayan ve karar alma süreçlerini gerçekleştirecek bir "kamusal iletişim mekanının" varlığ let-toplum arasında kurulacak demokratik bir yönetim için gereklidir (Keyman, 2000: 130).

Kamusal alan, aleniyetin tezahür ettiği, geleneksel toplumda yer bulamayan, tartışma konularının, değerlerin, sembollerin ve aktörlerin kendini ifade ettiği yerdir (Çaha, 2003: 79). Böylece aleniyet, kişiyi veya sorunu, kamusal akıl yürütmeye tabi tutarak, siyasal kararları kamuoyu önünde değiştirilebilir kılma rolü oynamaktadır (Habermas, 2003: 174).

Kamusal alan açısından kişisel özerkliği en önemli unsur olarak kabul eden Habermas'ın söylemsel kamu modelinde; kamusal eylem sürecine, ilgili herkesin sınırlandırılmaksızın katılması ve kamusal kararlardan etkilenecek herkesin demokratik yöntemlere dahil edilmesi esastır (Sarıbay, 2000: 6). Benhabib, Habermas'ın söylemsel kamu alanı modelini, herkesin katılımına ve her türlü konunun tartışmaya açık olması nedeniyle, demokratik meşruluğun ideal gerçekleşmesi olarak değerlendirir (Benhabib, 1992: 89).

Yapılan açılamalar ışığında kamusal alanı tüm toplumu kapsayacak biçimde genişletmek, toplumsal hareketlere de söz hakkı tanımayı gerektirir. Müzakereci Demokrasi yaklaşımının savunduğu müzakere ve diyalog süreci kamusal kararların meşruiyetini sağlar. Bu nedenle Gezi Parkı Eylemleri temsili demokrasinin meşruiyet krizini, toplumsal dayanışmayı ve farklı fikirlerin ortak paydada birleşebileceğini gösteren önemli örneklerinden biridir. Zira "Taksim Dayanışması” 128 
bileşenden oluşmakta ve ortak hareket edebilmektedir. Ortak hareket edebilmek için ön şart ise fikirlerin diyalog süreciyle kamusal alanda ifade edilebilmesidir.

Türkiye'de Gezi Parkı Eylemleri'yle dışa vurulan meşruiyet krizini aşmanın yolu müzakereci demokrasiden geçmektedir. Bu yöntem ise Greiff'e tarafından sistematikleştirilmiştir (Sitembölükbaşı, 2005: 149150): Müzakere, tartışma temelli, görüş alış verişine imkan tanıyan, herkese açık ve eşit katılım sağlayan, dış baskı olmadan ortak aklı ve eşit çıkarı hedefleyen, kesintisiz bir süreci amaç edinir. Gezi Parkı Eylemleri’nde eleştirilen temel konu, kamusal kararların müzakereye açık olmamasıydı. Dolayısıyla siyasal iktidar ve sivil toplum arasındaki mücadeleye müzakereci bir yöntemle yaklaşılmaması toplumsal ayrışmaya yol açmıştır. Ancak hükümet ve eylemlere destek verenler arasında hiçbir diyaloğun gelişmediğini iddia etmek yanlış olur.

Hükümetin eylemler devam ederken aydınlar ve Taksim Dayanışması’ndan katılımcılarla düzenlediği görüşme müzakere sürecini hayata geçiren adım olarak değerlendirilebilir. Bu görüşmede hükümet yargı kararı açıklanıncaya kadar Gezi Parkinda hiçbir tasarrufta bulunmayacaklarını, yargı kararı hükümet lehine çıksa da halkın taleplerini dikkate alacaklarını dile getirmiştir (Akşam Gazetesi, 13.05.2013).

Özetle, Türkiye'deki demokrasi algısı sandıkta temsil esasına dayandırılmıştır ancak Kymlicka’nın da (2006: 406) belirttiği üzere, demokratik kuramcılar artık sandık başında neler olup bittiğinden çok sivil toplumun kamusal tartışmalarına önem vermekte ve karar alma süreçlerinde toplumun müzakereci demokrasiyle daha iyi karar alabileceği görüşüne inanmaktadır. Bu nedenle Türkiye' de Temsili Demokrasi krizinin aşılması ve toplumsal kutuplaşmanın önlenmesi Müzakereci Demokrasi ile mümkündür.

\section{Sonuç}

Halkın iktidarı anlamına gelen demokrasi hükümet sistemi olarak değerlendirildiğinde ideal bir yönetim biçimidir. Ancak demokrasinin uygulanması ve demokratik yönetimin algılanması birbirlerinden farklı 
olgulardır. Bu nedenle ideal demokrasiye ulaşmak için tek araç seçim olmamalıdır. Demokrasinin bu şekilde algılanması meşruiyet krizine yol açmış ve Gezi Parkı Eylemleri'nde bu gerçeklik ortaya çıkmıştır.

Gezi Parkı Eylemleri'nin oluşmasında elbette birden fazla sebep vardır. Ancak genel olarak eylemlerin ortaya çıkmasında hükümetin uygulamalarının etkili olduğu gerçeklik taşımaktadır. Hükümet seçimler aracılığıyla ve yüksek oyla göreve başlamıştır. Ancak iktidarı ele geçirmek kamusal kararların alınmasında toplumun taleplerinin dikkate alınmayacağı anlamına gelmez. Bu nedenle özellikle bireylerin hayatlarını etkileyen kararlar alınırken konunun kamuoyunda tartışılması gereklidir. Ancak Kürtaj Yasa Tasarısı hazırlanırken kadınlara, alkol düzenlemesi yapılırken alkol tüketenlere/ satışını yapanlara söz hakkı tanınmamıştır. Dolayısıyla bu kararların uygulanması sürecinde toplumsal muhalefetin oluşması mümkündür.

Siyasal iktidarın "ortak iyi", "kamusal yarar" perspektifinden hareket etmesi gereklidir. Ancak ortak iyinin ve kamusal yararın ne olduğunu sadece kendisinin belirlemesi doğru değildir. Zira yurttaşların kendilerini toplumun bir parçası olarak kabul etmesi ve devlete aidiyetin sağlanması ancak çıkarları birleştirme yoluyla mümkündür. Çıkarları birleştirme süreci ise kamusal kararların müzakere sürecinden geçirilmesiyle mümkündür.

Demokrasi çoğunlukçuluktan ziyade çoğulculuğu esas aldığı müddetçe tam manasıyla söz konusudur. Aksi halde çoğunluğun azınlığa tahakkümünden başka bir şey değildir. Dolayısıyla devletin toplumla sağlıklı ilişkiler kurabilmesi toplumsal gruplar ve sınıflar arasında dengeli bir siyaset izlenmesine bağlıdır. Devlet tüm yurttaşlara eşit mesafede ve tarafsız olmalıdır. Bu ilkeler sağlanamadığı takdirde demokrasi azınlığa tahakkümden farklı bir şey değildir.

Gezi Parkı Eylemleri Türkiye'de demokrasi, iktidar, haklar tartışmasını yeniden gündeme getirmiş ve bu tartışmaların temeline "baskıya karşı direnmeyi” oturtmuş bir eylemdir. Söz konusu baskı bazen bireylerin özel alanlarına (çocuk sahibi olma, kürtaj hakkı, alkol düzenlemesi 
gibi) bazen de kamusal alanlarına (kent ve çevre hakkı, ulusal değerler gibi) yönelik düzenlemelerde kendini göstermiştir.

Gezi Parkı Eylemleri gerek örgütlenme ve eylem diliyle gerekse de demokrasi talebiyle Türkiye'de dönüm noktası ve demokrasi eşiğidir. $\mathrm{Bu}$ eylemler yönetsel kararlarda toplumun da söz sahibi olmak istediğini göstermiştir. Bu durum Türkiye'de demokrasi kavramının genişlediğini ve demokrasinin derinleştiğini göstermektedir.

Türkiye'de Gezi Parkı Eylemleri'ni oluşturan süreç değerlendirildiğinde, temsili demokrasinin kırılma noktaları başlığında incelediğimiz konuların müzakere sürecine dahil edilmesi durumunda toplumsal eylemlere yol açmayacağı kanısındayız. Zira müzakere süreci tarafların kamusal kararlar alınırken birbirini ikna edebileceği ortamı yaratabilir. Çatışma yerine diyaloğu esas alınması, meşruiyeti kararlara katılımla sağlaması sebebiyle Türkiye’nin demokratikleşmesinde Müzakereci Demokrasinin tercih edilmesi daha doğru olacaktır. 


\section{Kaynakça}

Açıkel, F. (2012). Muhafazakar Sosyal Mühendisliğin Yükselişi: 'Yeni Türkiye'nin Eski Siyaseti, Birikim Dergisi, Sayı: 276.

Arı, M. (2004) Düşük Yoğunluklu Demokrasi ve Türkiye 1980 Sonrası Dönemde Türkiye'de Demokratikleşme Süreci, A.Ü. Sosyal Bilimler Enstitüsü Kamu Yönetimi ve Siyaset Bilimi Anabilim Dalı, Doktora Tezi, Ankara.

Arslan, Z. (2005). Anayasalar ve Meşruluk Sorunu. (Ed.Adnan Küçük, Selahaddin Bakan, Ahmet Karadağ), Türkiye’de Siyasal Hayat. Cilt:1, İstanbul: Aktüel Yayınevi.

Ayata, G; Çağlı, P. vd. (2013). Gezi Parkı Olayları İnsan Hakları Hukuku ve Siyasi Söylem Işs̆ğında Bir İnceleme. İstanbul Bilgi Üniversitesi Yayınları.

Bakan, S. ; Arpac1, I. (2012). Liberal Değişim Sürecinde Dönüşen Ve Dönüştüren Muhafazakârlık. KSÜ İIBF Dergisi, Cilt:2, Sayı:2, ss.131-140.

Barry, N. P. (2004). Modern Siyaset Teorisi. Ankara: Liberte Yayınları.

Benhabib, Ş. (2013). Gezi Parkı Protestoları: Küresel Bağlam ve Türkiye'de Siyasetin Geleceği.http://bilimakademisi.org/wp-content/ uploads/2013/08/Gezi-Park\%C4\%B1-Protestolar\%C4\%B1_-K\%C3\%BCresel-Ba\%C4\%9Flam-ve-T\%C3\%BCrkiye\%E2\%80\%99de-Siyasetin-Gelece\%C4\%9Fi-_-Konu\%C5\%9FaKonu\%C5\%9Fa_0.pdf, web adresinden 20.12.2013 tarihinde alınmıştır.

Benhabib, Ş. (1992). Models of Public Space: Hannah Arendt, the Liberal Tradition, and Jürgen Habermas, Habermas and the Public Sphere. (Ed.) Craig Calhoun, Cambridge, Mass, MIT Pres. 
Bican, Ş. (2008). Demokrasi Teorisinde Güncel Tartışmalar. İstanbul: Orion Yayınevi.

Bölükbaşı, M. (2012). Milli Görüş’ten Muhafazakar Demokrasiye: Türkiye'de 28 Şubat Süreci Sonrası İslami Elitlerin Dönüşümü. İnsan ve Toplum Bilimleri Araştırmaları Dergisi, Cilt.1, Sayı:2, ss.166-189.

Çağlar, N. (2008). Postmodern Anlayışta Siyaset Ve Kimlik, Süleyman Demirel Üniversitesi İktisadi ve İdari Bilimler Fakültesi Dergisi. C.13, S.3 ss.369-386.

Çaha, Ö. (2005). Cumhuriyet ve Demokrasi. (Ed.Adnan Küçük, Selahaddin Bakan, Ahmet Karadağ), Türkiye'de Siyasal Hayat Cilt:1, İstanbul: Aktüel Yayınevi.

Çaha, Ö. (2003). Mahrem Kamusal Alan, Sivil Toplum Dergisi, Sayı:2.

Çarkoğlu, A. ; Toprak, B. (2006). Değişen Türkiye'de Din, Toplum ve Siyaset. İstanbul: TESEV Yayınları.

Dahl, R. (2010). Demokrasi Üzerine. (Çev. Betül Kadıŏlu), Ankara: Phoenix Yayınevi.

Denli, Ö. (2006). John Rawls’ın Halkların Yasası̉nda İnsan Hakları Düşüncesi, Sivil Toplum Dergisi, Sayı: 13.

Doğanay, Ü. (2007). AK PARTİ’nin Demokrasi Söylemi Ve Muhafazakarlık: Muhafazakar Demokrasi ve Eleştirel Bir Bakış, A.Ü.S.B.F. Dergisi, S:62, Cilt:1.

Dönmez, B. (2007). “TCK’da Çocuk Düşürtme Suçu, Mukayeseli Hukuk ve AİHM’nin Bakış Açısıyla Ceninin Yaşama Hakkının Sınırlandırılması", Dokuz Eylül Üniversitesi Hukuk Fakültesi Dergisi, Cilt: 9, Say1 2, ss. 99-141.

Erdoğan, M. (2003). Anayasal Demokrasi. Ankara: Orion Yayınları.

Erdomol, M. (2013). Gezi Parkı Dirnişi Küçük Bahçede Büyük Kıyamet. İstanbul: Yazılama Yayınevi.

Eren, A. (2005). Özgürlükler Mekanı Olarak Kamusal Alan, Atatürk Üniversitesi Erzincan Hukuk Fakültesi Dergisi, Cilt 9, S.3-4, ss.95-124. 
Görmez, K. (1997). Kent ve Siyaset. Ankara: Gazi Kitabevi.

Gündoğan, N. (2001). İşgücünün Yaşlanması Ve İşgücü Piyasalarına Etkileri, A.Ü. SBF Dergisi, Cilt:56, Sayı:4, ss.95-108.

Habermas, J. (2012). Kamusallığın Yapısal Dönüşümü. (çev. Tanıl Bora, Mithat Sancar), İstanbul: İletişim Yayınları.

Işık, M. (2005). Medya ve Demokrasi Paradoksu: Medya Yoluyla Demokrasinin Tehdit Edilmesi, Selçuk İletişim, Cilt: 3, Sayı: 4, ss. 114-121.

İHD (2013). Gezi Parkı Direnişi ve Sonrasında Yaşananlara İlişkin Değerlendirme Raporu, Ankara.

Kapani, A. (2010). Politika Bilimine Giriş. Ankara: Bilgi Yayınevi.

Karadağ, A. (2006). Kamusal Alan Modelleri: Çoğulcu Perspektiften Bir Değerlendirme, (Ed.), Kamusal Alan ve Türkiye, Ankara: Asil Yayınları.

Keleş, R. (1998). Kentbilim Terimleri Sözlüğü. Ankara: İmge Kitabevi.

Keleş, R. (2004). Kentleşme Politikası. Ankara: İmge Kitabevi.

Keyman, F. (2000). Türkiye ve Radikal Demokrasi Geç Modern Zamanlarda Siyaset ve Demokratik Yönetim. İstanbul: Alfa Yayınevi.

Kongar, E. ; Küçükkaya, A. (2013). Türkiye’yi Sarsan Otuz Gün Gezi Direnişi. İstanbul: Cumhuriyet Kitapları.

Köker, L. (1996). Radikal Demokrasi, Diyalog 1. Ankara: Türk Demokrasi Vakfi.

Kymlıcka, W. (2006). Çağdaş Siyaset Felsefesine Giriş. İstanbul: İstanbul Bilgi Üniversitesi Yayınları.

Lipset, M. (1964). Siyasal İnsan, (Çev.Mete TUNÇAY). Ankara: Türk Siyasi İlimler Derneği.

Mansbridge, J. (1999). Güç Kullanımı/Güçle Mücadele: Yönetim Biçimi, (Ed.Seyla BENHABİB), Demokrasi ve Farklılık Siyasal Düzenin S1nırlarının Aşılması, İstanbul: Demokrasi Kitaplığı. 
Özdemir, G. (2013). Farklılıkların Kesiştiği Coğrafyalar İçin Bir Öneri: Radikal Demokrasi, Celal Bayar Üniversitesi İ.İ.B.F. Yönetim ve Ekonomi Dergisi, Cilt:20 Sayı:1.

Sarıbay, A. Y. (2000). Kamusal Alan, Diyalojik Demokrasi ve Sivil İtiraz. İstanbul: Alfa Yayınları.

Sartori, G. (1996). Demokrasi Teorisine Geri Dönüş, (Çev. Tunçer Karamustafaoğlu ve Mehmet Turhan). Ankara: Yetkin Yayınevi.

Sitembölükbaşı, Ş. (2005). Liberal Demokrasinin Çıkmazlarına Çözüm Olarak Müzakereci Demokrasi, Akdeniz İ.I.B.F Dergisi, Sayı: 10, Antalya, ss.139-144.

Taştan, C. , Ete H. (2013). Kurgu İle Gerçek Arasında Gezi Eylemleri, Ankara: SETA Analiz.

Tosun, G. (2001). Türkiye'de Devlet- Sivil toplum İlişkisi Bağlamında Demokrasinin pekişmesinin Önündeki Engellere İlişkin Kuramsal ve Pratik Bir Yaklaşım, Ege Akademik Bakış, Cilt:1, Sayı

Tunç, H. (2008). Demokrasi Türleri ve Müzakereci Demokrasi Kavramı, Gazi Üniversitesi Hukuk Fakültesi Dergisi, C:XII, S.1-2.

Uçkaç, L. (2006). Kentsel Tasarımın Kent Kimliği Üzerine Etkileri: Keçiören Örneği, Yayımlanmış Yüksek Lisans Tezi, Ankara: Ankara Üniversitesi Fen Bilimleri Enstitüsü.

Yıldırım, Y. (2012). Yeni Toplumsal Hareketlerin Siyasal Alanı Belirlemedeki Rolü: Avrupa Sosyal Forumu ve Hareketlerin Avrupa'sını Kurmak, A.Ü. S.B.E. Siyaset Bilimi ve Kamu Yönetimi ABD, Doktora Tezi.

Yıldırım, Y. (2012). İşgal Et Hareketi Üzerine, A.Ü. S.B.F Dergisi, Sayı 67/1, ss. 238-244.

Young, M. (1999). İletişim ve Öteki: Müzakereci Demokrasinin Ötesinde, (Ed.Seyla BENHABİB), Demokrasi ve Farklılık Siyasal Düzenin S1nırlarının Aşılması, İstanbul: Demokrasi Kitaplığg.

Sabah Gazetesi, 28.01.2013.

Milliyet Gazetesi, 23.01.2013. 
Hürriyet Gazetesi, 28.01.2013.

Hürriyet Gazetesi, 22.05.2013.

Radikal Gazetesi, 23.06.2013.

Radikal Gazetesi, 31.05.2013.

Akşam Gazetesi, 13.05.2013.

Yeni Şafak Gazetesi, 08.06.2013.

Cnnturk.com, 28.01.2013

Tv24, 13.03.2014.

http://www.unicef.org/turkey/cedaw/_gil8.html, 28.01.2014.

http://www.tjod.org/turk-jinekoloji-ve-obstetrik-dernegi-tjod-kurtaj-raporu/, 28.01.2014.

http://www.ttb.org.tr/index.php/Haberler/kurtaj-3574.html, 28.01.2014. http://www4.cnnturk.com/2013/turkiye/01/02/erdogan.3.cocuk.talebini. yineledi/690965.0/, 28.01.2013.

http://www.tuik.gov.tr/PreHaberBultenleri.do?id=15844, 28.01.2013.

Abstract: -Representative Democracy and the Next Crisis of Democracy in Demand Action Gezi Park - This study offers some thoughts about the crisis of representative democracy during the Gezi Park protests. These thoughts are shaped out of opposition to policies of the government. In the study areas where democracy crisis is faced are evaluated regarding the debates in public sphere. Gezi Park Protests is an act of social protest that indicates increasing political polarization in Turkey. The existence of political polarization is obvious from the statements from both sides, protestors and government officials. This study within the framework of Turkish Political Culture evaluates Gezi Park protests as a social movement that proves the importance of political communication and dialogue and shows how democracy crisis can be solved. The actual reasons of these 
protests are inadequate political communication in decision-making process and disregarding demands of opposition. If Gezi Park protests are approached as a reflection of opposition to the government, attitudes of opposition and government differ. From the view that democracy includes different perspectives, this study claims that social consensus can be achieved through deliberative democracy. Because democracy is conceptually incorporating heterogeneity. Heterogeneity does not prevent coexistence of different thoughts; on the contrary, different thoughts are regarded as a richness of democracy. This study aims to provide a new paradigm of democracy. As democracy means more than the voting rates this study argues that the legitimacy of public decisions can be ensured via negotiations.

Key words: Gezi Parkı Protests, Democracy, Representative Democracy, Deliberative Democracy. 